\title{
Internet Service Provision under Authoritarian Rule: A Field Experiment in Belarus
}

\author{
Charles Crabtree $^{*} \quad$ Nils B. Weidmann ${ }^{\dagger}$
}

June 27, 2018

\begin{abstract}
Do authoritarian regimes strategically limit the opposition's Internet access? By constricting Internet access to potential challengers, governments can reduce the need to censor (since anti-regime content would be less likely to be produced and read) and also the need for large infrastructure shutdowns (which may harm the government). Cross-national work shows that political exclusion is associated with significantly lower rates of connectivity for the affected groups, but cannot tell us whether this pattern is because governments strategically limiting Internet access of the political opposition. We test this mechanism with a field experiment in Belarus. We email support centers of the national telecommunications provider and vary partisan cues in our emails. In line with the strategic exclusion mechanism, we find a tendency that opposition support leads to lower response rates for Internet-related service requests. Due to the low response rate, however, our findings largely fail to reach conventional levels of significance.
\end{abstract}

\footnotetext{
${ }^{*}$ Corresponding Author: Graduate Student, Department of Political Science, University of Michigan, 505 South State Street, Ann Arbor, MI 48109. ccrabtrumich.edu.

†Professor, University of Konstanz, nils.weidmannuni-konstanz.de. We would like to thank Allan Dafoe, Molly Roberts, and Yuri Zhukov for many helpful comments and suggestions. The design for the study was pre-registered with EGAP. Authors are listed alphabetically and contributed equally to study design, data collection, analysis, and manuscript preparation. All data files necessary to replicate the analysis presented in the article will be publicly available upon publication at dataverse repositories maintained by the authors.
} 


\section{Introduction}

The global expansion of digital communication, in particular the Internet, has opened up new channels of political debate and mobilization. Many argue that this should have a particularly profound impact in autocracies, where traditional media are often under strict control by the government (Friedrich and Brzezinski, 1965). With government censorship becoming more difficult in the digital realm, social media are assumed to provide new opportunities for regime-critical discussion, exposure of government abuse, and coordination for collective action. These opportunities, however, have not gone unnoticed by autocratic governments. This is why an emerging literature in comparative politics studies the various ways in which dictators respond to the potential threats arising from the expansion of the Internet. One obvious strategy a regime can employ is to shape digital content in its favor. This can be done either by eliminating unwanted content (King, Pan and Roberts, 2013), or by producing content that is explicitly supportive of the regime (Morozov, 2011). Other approaches autocratic governments can pursue target the underlying network infrastructure. For example, at the height of the Tahir Square protest, Hosni Mubarak of Egypt shut down the country's Internet, supposedly to prevent further escalation (Dainotti et al., 2014).

Both digital censorship and Internet shutdowns can entail significant risks for dictators: Censorship may be imperfect, such that the regime is unable to eliminate a large share of potentially threatening information. Shutting down the entire infrastructure also has important drawbacks, as it affects not only government opponents but also supporters, while at the same time cutting off Internet services also for government agencies. This is why recent research suggests that autocratic governments can pursue a different strategy: Rather than first providing Internet services and then having to (i) censor them at a high cost or (ii) turn them off entirely, it should be much more beneficial to make the provision of 
Internet service selective: governments afraid of dissent and mobilization catalyzed by the Internet should be hesitant to provide potential challengers with Internet services. This should significantly reduce both the need to censor (since regime-critical content would be less likely to be produced and read) and also the need for large infrastructure shutdowns (since the challengers would be less likely to use the Internet anyway).

Recent results from a large-N comparison of ethnic challengers worldwide indeed produces evidence consistent with this story (Weidmann et al., 2016). This research shows that political exclusion is associated with significantly lower rates of connectivity for the affected groups, which echoes existing results on ethnic favoritism and clientelism (Hodler and Raschky, 2014). However, while presenting strong evidence that Internet service provision seems to be biased against politically disadvantaged groups, this research cannot tell us whether the observed pattern is due to governments strategically limiting the Internet access of the political opposition. This paper aims to fill this gap. Using a field experiment in Belarus, we test whether opposition members suffer from "digital discrimination" when it comes to Internet service. More precisely, our experiment tracks responses to technical support inquiries to the national telecommunications provider in Belarus. These requests were sent via email and contain different cues as regards the sender's political orientation (pro/anti-regime).

While arguably only capturing one particular strategy of how regimes can discriminate digitally and reduce access to modern communication channels for particular groups, our focus on the quality of ICT-related support allows for a nuanced analysis. Most importantly, we are able to analyze if certain types of technology are of greater concern to an autocratic government than others. If rulers are wary of the collective mobilization potential introduced by technology, they should be most worried about the Internet but not conventional phones: while the Internet makes it possible to reach large numbers of activists with very little 
effort (broadcasting), this is much more difficult with phones since they offer only peerto-peer connectivity. Also, the possibility to openly criticize the government and expose misconduct and failure, both nationally and internationally, makes the Internet a potentially very dangerous tool for autocrats (Diamond, 2010). Therefore, we hypothesize that the quality of technical support should be lower for members of the opposition, but only if their requests refer to the Internet (and not to conventional phone services). Before we describe the experiment that tests this hypothesis, we first provide some information about the context in which we conducted it.

\section{Theory}

\section{Case Selection}

In this section, we provide additional details about Belarus, the country where we implemented our experiment. A land-locked country in Eastern Europe, Belarus is relatively small, with an area about the size of Kansas, and a population of around 10 million. A young country, it only became a sovereign state after the Union of Soviet Socialist Republics (U.S.S.R.) dissolved in 1991 (Keep, 1995). ${ }^{1}$ Belarus undertook large-scale political reforms in the years after the fall of the Soviet Union, and for a time was considered a democratizing leader within the region (Zaprudnik, 1993). The country's freedom from dictatorial rule was short-lived, however, ending with the election of Alexander Lukashenko in the 1994 presidential election (Marples, 1996, 1999). After expanding and consolidating his control over the state through two popular referenda, Lukashenko embarked on a series of policy programs aimed at entrenching his authoritarian rule. The first of these is a bundle of social

\footnotetext{
${ }^{1}$ It existed, however, in various forms as a semi-sovereign territory or state in the Grand Duchy of Lithuania, the Russian Empire, and then the Soviet Union (Wilson, 2011; Snyder, 2003).
} 
welfare programs that subsidize prices and limit employment (Way, 2005). The second is the establishment and maintenance of a security apparatus - reportedly the largest in Europe - that oversees a massive surveillance program (Silitski, 2005, 2009, 2010). The third is an active state media policy, which aims to quiet dissenting voices while creating and broadcasting pro-regime content (White, Korosteleva and Löwenhardt, 2005). Taken together, these programs have succeeded in creating public acquiescence to his rule if not stimulating universal support (Wilson, 2011). Indeed, Lukashenko won his fifth term as president in the 2015 election, virtually extending that his time as chief executive will extend until 2020, if not later (Crabtree, Fariss and Schuler, 2016).

All of these reasons make Belarus an interesting in which case to conduct political science research. The primary reason, though, why we selected Belarus as our case - as the place to conduct our experiment — was because it is considered to be among the world's worst at restricting the free speech rights of its citizens. The state is ranked 157 th out of 180 countries according to Reporters without Borders (2015), and Freedom House (2015) ranks Belarus as one of the 10 worst violators of free speech rights. While continuing economic needs have pushed the state to develop Internet service throughout the country, Belarus' president, Alexander Lukashenko, has used a variety of media control strategies to significantly reduce the Internet's usefulness as a political tool (Wilson, 2011; White, Korosteleva and Löwenhardt, 2005; Marples, 1996, 1999). Perhaps most importantly, all connections to foreign servers must travel through Beltelecom, the state-owned telephone and Internet service provider (Index on Censorship, 2013). This means that all Internet connections to foreign websites, such as google.by, must ultimately pass across government servers. In addition, Lukashenko has made criticism of public officials illegal, prohibited access to pro-opposition websites, and enacted a series of laws that require Internet service providers (ISPs) to monitor and record what individuals do online (Index on Censorship, 2013). Given the range of 
tactics used by the regime to control the Internet, we should expect that they might, given the opportunity, limit or impede Internet service provision to the opposition.

Whether they actually do so is difficult to observe, however. Belarusian Internet users often experience intermittent access and variable download and upload speeds. While the state has the technical capabilities to identify the partisan affiliation of Internet users through their browsing habits (Index on Censorship, 2013), the extent to which they actually do this is unknown. There is some speculation, however, that the regime does throttle the Internet speeds of those who might seek to oppose it. We know this because of a series of interviews one of the authors conducted with high-level members of the opposition in December 2013. ${ }^{2}$ The idea behind tis strategy, they claimed, was that the regime cannot afford to openly oppose political dissidents; doing so could increase Western pressure and put the regime in a difficult position for securing the international financial assistance upon which its social-welfare policies depend (Allison, White and Light, 2005; White, McAllister and Feklyunina, 2010). Given this constraint, the regime instead does what it can to increase minor impediments to behavioral challenges. ${ }^{3}$ In this case, by intermittently slowing down or stopping Internet access, they are able to increase friction and deter opposition action. ${ }^{4}$ Ultimately, however, the individuals that one author spoke with were unable to provide any rigorous evidence that the Internet problems they experienced were the result of their political views. As a result, it is difficult to ascertain if there is a relationship between the partisan affiliation of users and the difficulties that they experience connecting to and remaining on the Internet.

\footnotetext{
${ }^{2}$ To preserve the anonymity of these individuals, we do not provide identifying information about them. This is in keeping with best practices for conducting and reporting interviews with at-risk subjects (Aberbach and Rockman, 2002; Leech, 2002; Mosley, 2013; Driscoll, 2015).

${ }^{3}$ Other impediments listed by members of the opposition include increases in fees related to protest permits, printing materials, and even mailing supplies.

${ }^{4}$ This claim is in line with Roberts (2014)'s theoretical argument.
} 


\section{Research Design and Methods}

We test whether this difficult to observe behavior occurs by conducting an audit study. An audit study, also know as a correspondence study, is an experimental approach designed to identify hard-to-observe phenomena (Gaddis, 2017; Heckman, 1998). ${ }^{5}$ The basic design of an audit study is uncomplicated and includes only a few steps. First, a set of fictional identities need to be created. These identities share the same attributes except one, such as gender or race, which is randomized by researchers. After creating these identities, scholars would then use them to do something — whether it be applying for school, contacting employers about vacancies, soliciting information on housing, or asking political elites for help. Finally, researchers examine the extent to which individuals respond similarly to the fictional identities, attributing any evidence of differential treatment as evidence of some latent bias. For example, if politicians respond to a White identity more frequently than a Hispanic identity, then researchers would argue that politicians are biased against Hispanics. Because audit studies are simple to design and implement, researchers have used them to investigate the existence of bias in a wide range of important contexts (Butler, 2014; Broockman, 2013; Butler and Broockman, 2011; Grose, 2014; Costa, N.d.; Gaddis and Ghoshal, 2015; Turner et al., 2002; Hogan and Berry, 2011; Oh and Yinger, 2015; Riach and Rich, 2002; Neumark, Bank and Van Nort, 1995; Bertrand and Mullainathan, 2004; Pager and Shepherd, 2008).

In our audit study, we posed as a Beltelecom customer and emailed support centers with requests for technical assistance (see Appendix S1 for the email template). Our sample consists of 106 customer support centers that Beltelecom listed as operational on their website (http://beltelecom.by/) in January 2016 (see Appendix S1 for additional details about this sample). One set of requests centered on Internet access problems. While emailing sup-

\footnotetext{
${ }^{5}$ Gaddis (2017) provides an extensive history of audit studies and an overview of the approach.
} 
port centers about Internet problems might be strange in the American context, our prior experience living and conducting fieldwork in Belarus suggests that it is a reasonable intervention there for several reasons. First, Belarusians usually have problems getting technical support over the phone, so they often email support centers from work. Second, customers might want to contact support centers via email to document their request and potentially increase the possibility of a resolution. The expectation here is that since over-the-phone requests are not necessarily documented, customer support personnel might be less likely to address them than written requests. One of the authors lived in Belarus for two years and emailed their support center for these very reasons.

To test whether the regime prefers to limit opposition access to the Internet, we randomly varied the partisan signal we included in the email. In keeping with our discussion of audit studies above, this is equivalent to manipulating the partisanship of the identities we created. Specifically, we included either a pro-regime, anti-regime, or non-partisan cue in each email. We signaled pro-regime or anti-regime partisanship by including a political slogan in the email signature. For the pro-regime cue, we use a campaign slogan associated with Lukashenko's 2006 presidential campaign - 'For Belarus!'. This slogan is commonly known and associated with Lukashenko, as it regularly appears in government-owned mass and online media. For the anti-regime cue, we use a common slogan of the opposition - 'Belarus is living!'. This slogan has been used by the opposition in multiple campaigns and is often chanted at pro-opposition rallies. We did not include a political slogan in emails assigned to the non-partisan condition (see Appendix S2 for additional details about the partisanship cues, English translations, and discussions of the construct validity of these treatments). The logic here is that if the telecom company responded to emails with an anti-regime cue at a lower rate than emails with a non-partisan or pro-regime cue, this suggests that the regime prefers to strategically limit the opposition's Internet access. 
This interpretation, however, would also be consistent with an alternative explanation. Perhaps individuals who work for the state-run Internet provider simply dislike members of the opposition. If this is the case, then a lower response rate is not necessarily evidence of a strategic calculation on behalf of the regime and its agents but might instead be evidence of a general antipathy toward the opposition. To distinguish between these two possible explanations, we also randomly varied whether support centers received a request about connecting to the Internet or about making domestic phone calls. The support centers are supposed to help customers with both types of problems. If support center employees simply dislike members of the opposition, they should respond to both types of requests at similar rates. If, on the other hand, they want to limit the opposition's Internet access, they should respond to opposition requests for Internet support at a lower rate than opposition requests for telephone support. This is because while the regime might fear the opposition speaking with other individuals across the country, it should fear even more the opposition using the Internet to potentially inform and mobilize individuals (see Appendix S3 for these requests and their English translations).

In addition, these two types of requests (Internet/domestic phone service) are intended to capture different potentials of the two communication technologies to foster collective action. Compared to traditional phones, Internet communication should be more likely to be used to stage protest, and therefore perceived to be more threatening to the regime. Note that this does not presuppose that domestic phones cannot be used to organize collective action - of course they can, but the effectiveness of individual calls, and therefore the threat to the regime, is much lower. In other words, our two types of requests capture the latent treatment ("threat of collective action") only imperfectly, which will lead to measurement error in the treatment. However, since this error is random, it will lead to attenuation in our effect estimates, and should therefore be not be a real danger for our experiment. 
To recap, we used a $3 \times 2$ fully crossed factorial design. The first factor varied the partisanship of the sender. This factor had three levels: pro-regime, anti-regime, and nonpartisan. The second factor varied the type of request. We included requests for assistance with either Internet access or domestic phone service. The entire email template is shown in Appendix S1.

Once concern with this design is that we might not have sufficient statistical power to identify substantively important treatment effects. To increase power, we used a withinsubjects design. This meant that we sent each support center in our sample six emails, one for every treatment condition. Our data then consist of observations for 106 support centers taken over 6 periods of time $(n=636)$.

We randomized the order of our requests to reduce the possibility of carryover effects. To help ensure that the repeated emails did not alert subjects to the existence or intent of our study, we sent the emails over the course of six weeks, waiting approximately a week between requests. We also sent slightly different variations of each request, so that no participant received an email with the exact same language twice. In our analysis below, we average over the different variations of requests but not the different types. In addition, we randomized the names and email accounts of the putative customer so that no center received an email from the same customer twice. Finally, we randomized the subject lines of the emails, the valedictions that we included, and the type of ASCII divider that we included before the email signature (see Appendix S4 for names, email addresses, subject lines, valedictions, and dividers). The idea was that by introducing some random variation to these email components our subjects might be less likely to notice patterns among the requests. While we cannot completely rule out the possibility that subjects knew they were part of an experimental study - no experimentalist can — we think that this possibility is unlikely in our case. Indeed, we received no email replies from support centers that suggest that they did not take our 
requests at face value.

Our outcome measure is EMAIL RESPONSE. It is coded 1 if a support center replied to our email and 0 otherwise. We do not count auto-responses as replies. The next section of the paper presents the empirical results.

\section{Ethics Statement}

The study plan was submitted to the IRB on Nov 24, 2015. The IRB deemed it unnecessary to conduct a full review and issued a waiver of ethical approval on Nov 28, 2015. Participants

did not reveal their identity during the email communication, which is why no identifying information was collected. Due to the fact that we were emailing to a general support email address, it was impossible to ascertain that the individuals who received our first email are the same who would receive our debriefing email. This is why participants were not debriefed due to the possibility of harm for them: If an individual other than the original responder were to receive the debriefing email, the second individual could possibly sanction the first individual.

\section{Results}

Before analyzing our data, we first visualize and describe it. Fig 1 provides an overview of our Email Response outcome. The left panel provides frequency counts for emails that were responded to (green) and those that were not (red). The overall response rate was 11.16 percent. The center panel shows the number of centers that did not reply to any of our emails (red) and the number of centers that replied to at least one of our emails (green). It highlights that responses came from only 16 unique centers. This means that about 85 percent of the centers in our sample did not reply to our inquiries. The right panel plots the 
number of centers that did not reply to any of our emails (red) and the number of centers that replies to 1-6 of our emails (green). In fact, among the centers that did reply, the response rate was 73.96 percent.

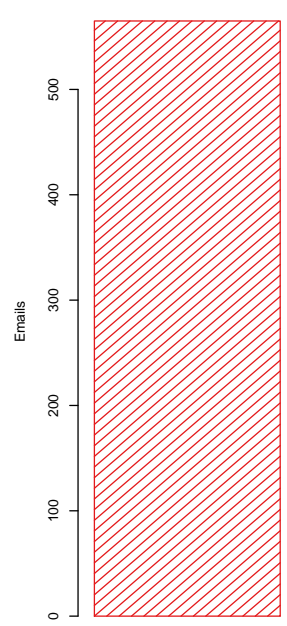

No Response

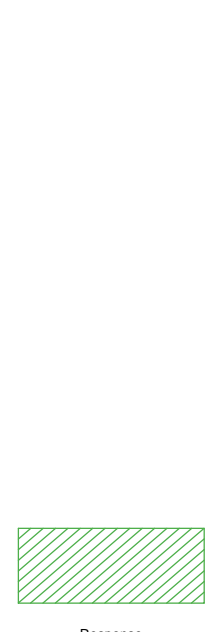

Response

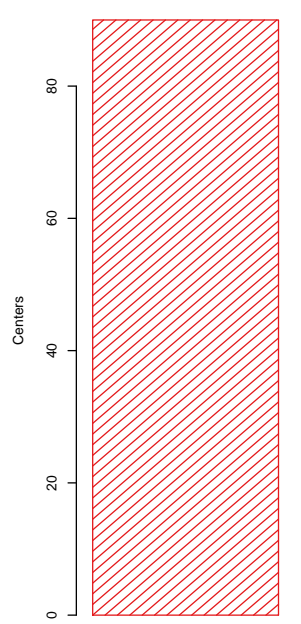

No Response

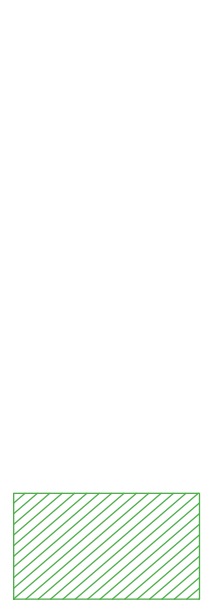

Response

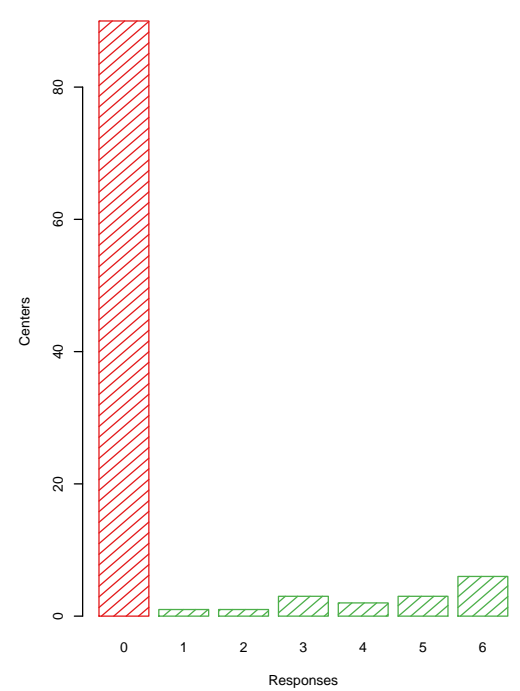

Figure 1: Overview of our EMAIL Response outcome. The left panel provides frequency counts for emails that were responded to (green) and those that were not (red). The center panel shows the number of centers that did not reply to any of our emails (red) and the number of centers that replied to at least one of our emails (green). The right panel shows the number of centers that did not reply to any of our emails (red) and the number of centers that replied to 1-6 of our emails (green).

There are several possible explanations for the low overall response rate. First, centers might be generally poor at responding to customer service requests. Second, the majority of centers might only respond to persistent customers, which means that the response rate might have been higher if we had sent multiple requests from the same putative customer to each center. Third, even though we worked hard to make our emails believable, they might have been suspicious enough to dissuade the majority of centers from replying. Fourth, some of the support centers might no longer be responding to requests for technical information. The support center listings at http://beltelecom.by/ are clearly outdated, as a large number 
of their center listings contained invalid email addresses. It might be that some of the centers listed on the site have either stopped operating or stopped replying to requests like ours. We return to and extend these explanations later in the paper.

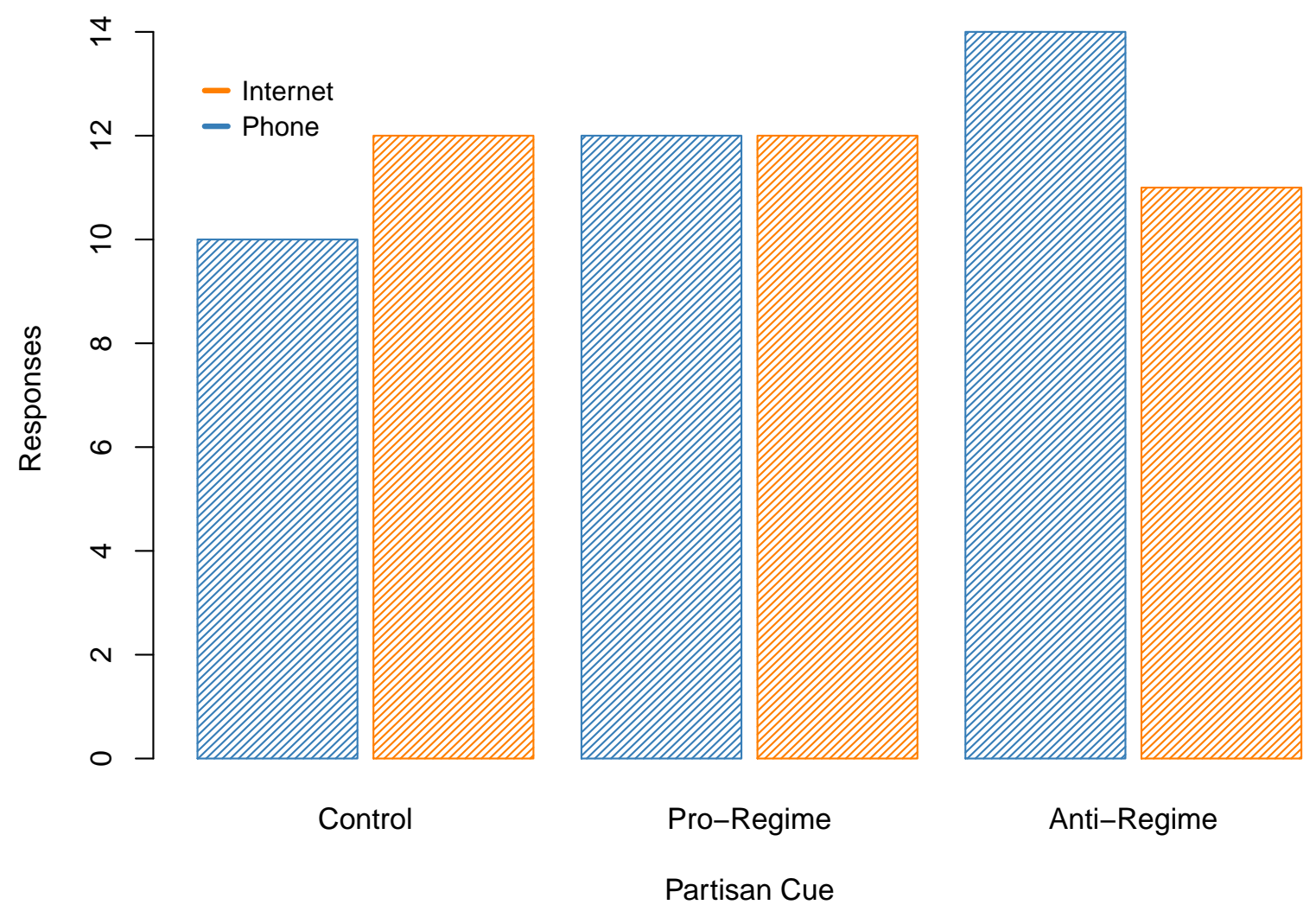

Figure 2: Number of responses received across our six treatment arms.

Do the number of responses that we did receive vary based on treatment conditions? Fig 2 presents the number of responses received across our six treatment arms. As we expected, centers were less likely to reply to our Internet requests when they contained an anti-regime treatment (11 replies, compared to 12 replies for the pro-regime and non-partisan conditions). Also in line with our expectations, centers were less likely to reply to regime opponents that 
asked about Internet problems (11 replies) than regime opponents who asked about telephone problems (14 replies). These differences are small, though, and call into question whether our experimental treatments actually influenced support center responsiveness. A $\chi^{2}$ test tells us that we cannot reject the null that email replies are independent of our experimental treatments $(p=0.9744)$. This is not surprising, as the low response rate reduces statistical power and thereby our ability to discover real effects.

Despite this result, we still might be interested in estimating treatment effects. To do this, we use a linear probability model (LPM). To account for heterogeneity in the error term, we use robust standard errors (Angrist and Pischke, 2008). The outcome measure is Email Response. On the right-hand side of the equation, we include dummies for the Anti-Regime and Pro-Regime treatment, a dummy for the Internet treatment, and Anti-Regime $\times$ Internet and Pro-Regime $\times$ Internet interaction terms. Since we used a within-subjects design, sending different emails to the same support centers, we also include fixed effects for support centers.

We use an LPM because the results are easier to interpret and because its estimates are unbiased if the model is specified correctly. This is true here since we only include dummy variables (Wooldridge, 2010). An alternative modeling strategy would be to use a conditional logit model. A conditional logit model would be preferred to a standard logit model because we use fixed effects and have a small number of measures for each unit. In this case, estimates from unconditional logit models are more biased than estimates from conditional logit models (Katz, 2001; Coupé, 2005). We present results from a conditional logit model in Appendix S6. They are substantively similar to the results from an LPM, except the $p$-values for our treatments are actually smaller. We present the LPM results here because they are more conservative. Ultimately, we cannot be sure which model is the right one (Angrist and Pischke, 2008) - but the fact that both models suggest the same general 
relationships makes us more confident in our interpretation of the results.

Fig 3 presents the results of the LPM model (see Appendix S5 for tabular results). The left panel plots the estimated coefficients (black points) from the model along with $90 \%$ confidence intervals (gray bars). The reference group is emails with the non-partisan cue and the domestic phone service request. It shows that the estimated coefficient for ANTIREGIME $\times$ INTERNET is negative, which suggests that the regime opponents are less likely to receive a response when they send an Internet request as opposed to a telephone request. This is in line with our theoretical expectations. The coefficient for this variable is estimated imprecisely, though, so we cannot draw strong conclusions from these results.

The right panel plots the marginal effect of ANTI-REGIME across request types (black points) along with $90 \%$ confidence intervals (gray bars). If our theory is correct, we should see that the effect of the anti-regime treatment is negative when it appears in emails with requests for Internet assistance. The right panel provides some support for our argument by showing that marginal effect of ANTI-REGIME is negative when emails contain Internetrelated requests. The $90 \%$ confidence interval for this marginal effect contain 0 , however.

These results provide some tentative evidence in favor of the strategic exclusion mechanism. They show that stated support for the opposition appears to lead to a lower response rate, but only for Internet-related service requests.

To this point, though, we have only examined whether our experimental treatments influence if support centers reply to our requests. Not responding is only one potential way that support centers could encumber access to the Internet. Another way that they can do this is by not responding to our requests or by providing useless information. To account for this, we create a second outcome, Helpful Email, captures the nature of email replies. It is coded 1 if we received a helpful response and 0 otherwise. This coding treats unhelpful responses the same as 'no responses.' Using this variable as our outcome measure, we find 

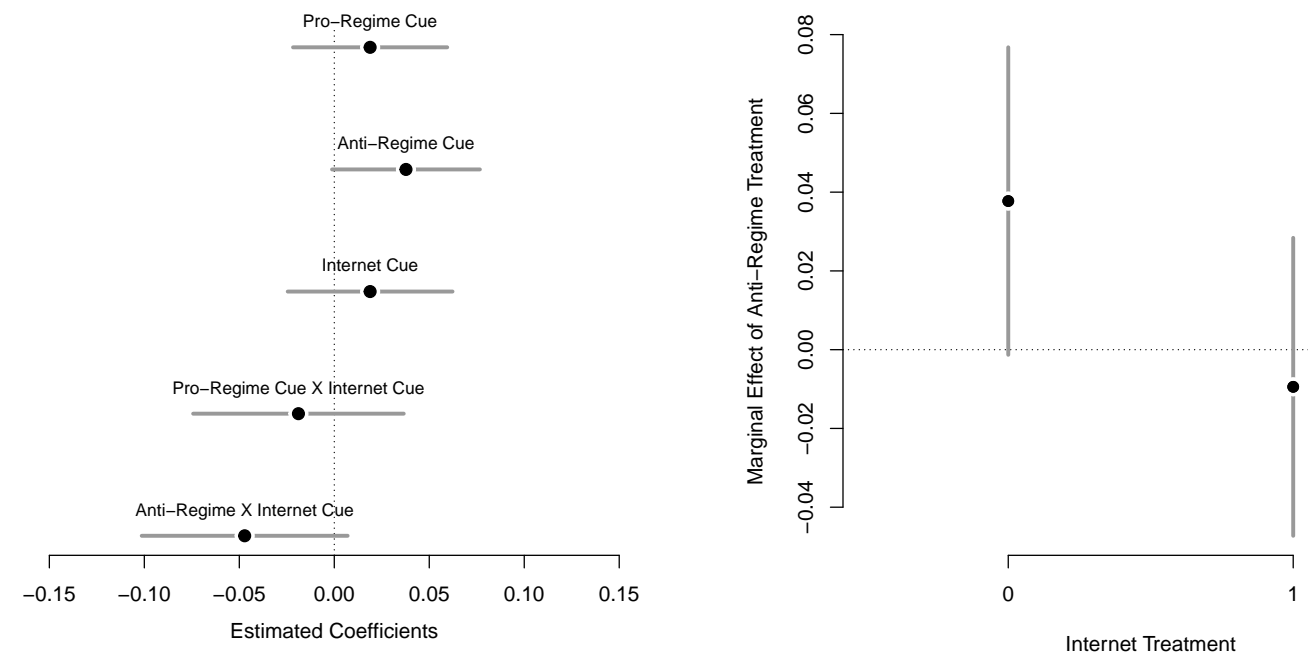

Figure 3: Results of LPM model. The outcome measure is Email RESPOnsE. The left panel plots the estimated coefficients (black points) from the model along with $90 \%$ confidence intervals (gray bars). The reference group is emails with the non-partisan cue and the domestic phone service request. The right panel plots the marginal effect of ANTI-REGIME across request types (black points) along with $90 \%$ confidence intervals (gray bars). 
additional empirical support for the strategic exclusion mechanism. Appendix S7 contains these results.

\section{Discussion}

In this paper, we reported the results of a field experiment in Belarus to test whether the regime curtails the opposition's access to the Internet. We emailed support centers of the national telecommunications provider and varied partisan cues in our emails. In line with the strategic exclusion mechanism, we found a tendency that stated support for the opposition leads to a lower response rate, but only for Internet-related service requests. However, due to the low response rate, our findings largely fail to reach conventional levels of significance.

Despite our weak findings, we remain confident that experiments like ours can be used to identify the extent to which strategic exclusion occurs both in Belarus and in other countries. In the remainder of the paper, we briefly highlight several limitations related to the design and implementation of our experiment and provide suggestions about how researchers might be able to address these issues. We hope that this discussion will encourage others to conduct similar experiments.

The largest problem with our experiment is that few support centers responded to our emails. While there are several possible explanations for this, as we discussed above, we think that some of the most likely explanations center on design and implementation choices that we made. First, we created our participant pool using publicly available data from Beletelecom's official website. Unfortunately, we did not know then, and cannot know now, the accuracy of that data. Based on the large number of invalid email addresses that were included in that data, we have reason to believe that some of the support centers on the list no longer exist. The low response rate to our requests suggest that others might operate 
in reduced capacity or not at all. If we were to do this again, we would have attempted to interview one or more Beltelecom workers. These employees might have been able to identify the invalid entries in our sample data.

Second, we sent our emails from custom domains, such as bmorozov.org. We did this because custom domain accounts do not face the same sending limits as free email account services, such as gmail.com or mail.ru. While this approach allowed us to automate and speed up message delivery, it also might have caused our emails to stand out. Most support center personnel probably deal with requests from mail.ru or yandex.ru. We recommend that scholars use freely available, innocuous email services to deliver their messages, even if that requires that they send their emails manually and slowly.

Third, we only emailed support centers once. This might be a problem because support centers might only reply to persistent customers. It also might be the case that support centers that could not immediately reply reasoned that if we did not email them again, we must have solved the problem. One way to address this problem would have been to email support centers at least twice.

We think that by keeping these issues in mind, others can improve on our design and implementation and better test the underlying theory. 


\section{References}

Aberbach, Joel D and Bert A Rockman. 2002. "Conducting and coding elite interviews." PS: Political Science Eீamp; Politics 35(4):673-676.

Allison, Roy, Stephen White and Margot Light. 2005. "Belarus between east and west." Journal of Communist Studies and Transition Politics 21(4):487-511.

Angrist, Joshua D and Jörn-Steffen Pischke. 2008. Mostly Harmless Econometrics: An Empiricist's Companion. Princeton, NJ: Princeton University Press.

Bertrand, Marianne and Sendhil Mullainathan. 2004. "Are Emily and Greg More Employable Than Lakisha and Jamal? A Field Experiment on Labor Market Discrimination." American Economic Review 94(4):991-1013.

Broockman, David E. 2013. "Black politicians are more intrinsically motivated to advance Blacks' interests: A field experiment manipulating political incentives." American Journal of Political Science 57(3):521-536.

Butler, Daniel M. 2014. Representing the Advantaged: How Politicians Reinforce Inequality. Cambridge University Press.

Butler, Daniel M and David E Broockman. 2011. "Do politicians racially discriminate against constituents? A field experiment on state legislators." American Journal of Political Science 55(3):463-477.

Costa, Mia. N.d. "How Responsive are Political Elites? A Meta-Analysis of Experiments on Public Officials." . Forthcoming.

Coupé, Tom. 2005. "Bias in Conditional and Unconditional Fixed Effects Logit Estimation: A Correction." Political Analysis 13(3):292-295. 
Crabtree, Charles, Christopher J Fariss and Paul J Schuler. 2016. "The presidential election in Belarus, October 2015.".

Dainotti, Alberto, Claudio Squarcella, Emile Aben, Kimberly C. Claffy, Marco Chiesa, Michele Russo and Antonio Pescapé. 2014. "Analysis of Country-wide Internet Outages Caused by Censorship." IEEE/ACM Transactions on Networking 22(6):1964-1977.

Diamond, Larry. 2010. "Liberation Technology." Journal of Democracy 21(3):69-83.

Driscoll, Jesse. 2015. Warlords and Coalition Politics in Post-Soviet States. Cambridge University Press.

Freedom House. 2015. "Freedom of the Press Index." Online Resource. Available at https: //freedomhouse.org/report/freedom-press/freedom-press-2016.

Friedrich, Carl J. and Zbigniew K. Brzezinski. 1965. Totalitarian Dictatorship. Cambridge, MA: Harvard University Press.

Gaddis, S. Michael. 2017. An Introduction to Audit Studies in the Social Sciences. In Audit Studies: Behind the Scenes with Theory, Method, and Nuance, ed. S. Michael Gaddis. Methodos Series New York, NY: Springer.

Gaddis, S Michael and Raj Ghoshal. 2015. "Arab American Housing Discrimination, Ethnic Competition, and the Contact Hypothesis." The ANNALS of the American Academy of Political and Social Science 660(1):282-299.

Grose, Christian R. 2014. "Field Experimental Work on Political Institutions." Annual Review of Political Science 17.

Heckman, James J. 1998. "Detecting discrimination." The Journal of Economic Perspectives $12(2): 101-116$. 
Hodler, Roland and Paul A Raschky. 2014. "Regional Favoritism." The Quarterly Journal of Economics 129(2):995-1033.

Hogan, Bernie and Brent Berry. 2011. "Racial and ethnic biases in rental housing: An audit study of online apartment listings." City Eamp; Community 10(4):351-372.

Index on Censorship. 2013. "Belarus: Pulling the Plug." Policy Brief. Available at https://www.indexoncensorship.org/wp-content/uploads/2013/01/IDX_Belarus_ ENG_WebRes.pdf.

Katz, Ethan. 2001. "Bias in Conditional and Unconditional Fixed Effects Logit Estimation." Political Analysis 9(4):379-384.

Keep, John LH. 1995. Last of the empires: a history of the Soviet Union, 1945-1991. Oxford University Press, USA.

King, Gary, Jennifer Pan and Margaret E. Roberts. 2013. "How Censorship in China Allows Government Criticism but Silences Collective Expression." American Political Science Review 107(2):1-18.

Leech, Beth L. 2002. "Interview methods in political science." PS: political science EGamp; politics $35(4): 663-664$.

Marples, David. 1996. Belarus: from Soviet rule to nuclear catastrophe. Springer.

Marples, David R. 1999. Belarus: a denationalized nation. Vol. 1 Taylor \& Francis.

Morozov, Evgeny. 2011. The Net Delusion: The Dark Side of Internet Freedom. Philadelphia: PublicAffairs.

Mosley, Layna. 2013. Interview research in political science. Cornell University Press. 
Neumark, David, Roy J Bank and Kyle D Van Nort. 1995. Sex discrimination in restaurant hiring: an audit study. Technical report National Bureau of Economic Research.

Oh, Sun Jung and John Yinger. 2015. "What Have We Learned From Paired Testing in Housing Markets?" Cityscape 17(3):15.

Pager, Devah and Hana Shepherd. 2008. "The sociology of discrimination: Racial discrimination in employment, housing, credit, and consumer markets." Annual review of sociology 34:181.

Reporters without Borders. 2015. "Press Freedom Index." Online Resource. Available at https://rsf.org/en/.

Riach, Peter A and Judith Rich. 2002. "Field experiments of discrimination in the market place." The economic journal 112(483):F480-F518.

Roberts, Margaret E. 2014. Fear, Friction, and Flooding: Methods of Online Information Control. Harvard University.

Silitski, Vitali. 2005. "Preempting democracy: The case of Belarus." Journal of Democracy $16(4): 83-97$.

Silitski, Vitali. 2009. "Tools of autocracy." Journal of Democracy 20(2):42-46.

Silitski, Vitali. 2010. "'Survival of the fittest:" Domestic and international dimensions of the authoritarian reaction in the former Soviet Union following the colored revolutions." Communist and Post-Communist Studies 43(4):339-350.

Snyder, Timothy. 2003. "The reconstruction of nations." Poland, Ukraine, Lithuania, Belarus pp. 1569-1999. 
Turner, Margery A, Stephen Ross, George C Galster and John Yinger. 2002. Discrimination in metropolitan housing markets: national results from phase 1 of the housing discrimination study (HDS). Technical report.

Way, Lucan A. 2005. "Authoritarian state building and the sources of regime competitiveness in the fourth wave: The cases of Belarus, Moldova, Russia, and Ukraine." World Politics $57(2): 231-261$.

Weidmann, Nils B., Suso Benitez-Baleato, Philipp Hunziker, Eduard Glatz and Xenofontas Dimitropoulos. 2016. "Digital Discrimination: Political Bias in Internet Service Provision across Ethnic Groups." Science 353(6304):1151-1156.

White, Stephen, Elena A Korosteleva and John Löwenhardt. 2005. Postcommunist Belarus. Rowman \&amp; Littlefield.

White, Stephen, Ian McAllister and Valentina Feklyunina. 2010. "Belarus, Ukraine and Russia: east or west?" The British Journal of Politics Eamp; International Relations $12(3): 344-367$.

Wilson, Andrew. 2011. Belarus: The Last European Dictatorship. New Haven, CT: Yale University Press.

Wooldridge, Jeffrey M. 2010. Econometric Analysis of Cross Section and Panel Data. Cambridge, MA: MIT Press.

Zaprudnik, Jan. 1993. Belarus: at a Crossroads in History. Westview press. 


\section{Supplementary Information for "Internet Service Provision under Authoritarian Rule: A Field Experiment in Belarus"}




\section{Appendix S1: Additional Details About Experiment}

\section{Email Template}

Text in $<>$ represents randomly assigned elements.

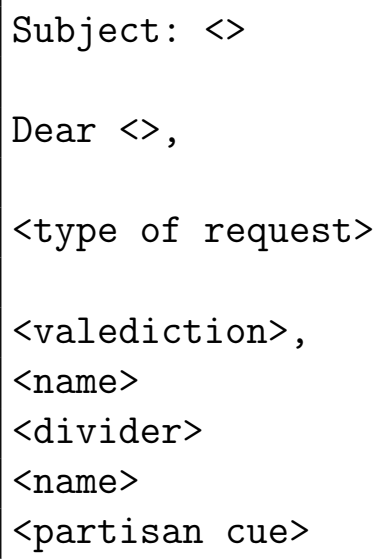

\section{Additional Details about Our Sample}

Beltelecom lists 146 operating support centers but 21 of them share email addresses with other support centers. We removed duplicate email address entries by randomly selecting one center to stay in our sample and dropping the others. We also dropped 3 centers prior to implementation because Beltelecom provided incomplete email addresses for them and another 18 centers after implementation because the emails addresses were invalid.

\section{Treatments}

Treatments manipulated the partisan affiliation of the sender and the type of assistance requested.

- Partisan affiliation - indicated by whether the signature contains a pro-regime quote, an anti-regime quote, or no quote in the email signature.

- Type of request - indicated by whether sender requests assistance with Internet service or domestic phone service. 


\section{Appendix S2: Partisan Cues}

\section{Partisan Cues}

\section{Pro-Lukashenko}

For the pro-Lukashenko cue, we used a campaign slogan associated with his 2006 presidential campaign. This slogan is commonly known and associated with Lukashenko, as it regularly appears in government-owned mass and online media. The phrase also appears on government-owned billboards throughout the country, appearing alongside idealistic representations of the country and its people. It is also a popular slogan used by the Belarusian Republican Youth Union (BRSM), a pro-Lukashenko youth group.

\section{Russian}

За Беларусь!

\section{English translation}

(For Belarus!)

\section{Anti-Lukashenko}

For the anti-Lukashenko cue, we used a common slogan of the opposition. This slogan has been used by the opposition in multiple campaigns and is often chanted at pro-opposition rallies. The slogan was banned from being said at soccer matches or other public gatherings. The slogan is also the name of a popular Belarusian documentary about the opposition. We expect then that this slogan was correctly interpreted as a signal of opposition to Lukashenko's rule.

\section{Russian}

Жыве Беларусь!

\section{English translation}

(Belarus is living!)

These cues also have the benefit of being roughly similar length: the anti-Lukashenko cue is only two letters longer than the pro-Lukashenko cue. 


\section{Appendix S3: Email Requests}

\section{Request texts}

\section{Internet requests}

\section{1}

English text:

I'm having problems with my home Internet service. I think that there might be an issue with the telephone jack or wiring. Could you give me the direct number of the department that deals with physical damage to the line?

Russian translation:

у меня дома не работает Интернет. Я думаю, что проблемы с сервисом возникли из-за повреждения телефонной розетки или проводки. Я знаю общий номер техподдержки (123), но хотел бы позвонить напрямую в отдел, который занимается механическими повреждениями линии по моему месту жительства. Не могли бы Вы дать мне их прямой телефонный номер?

Russian-to-English translation:

The Internet in my home does not work. I think that the problem with the service occurred due to mechanic damage to the telephone jack or wiring. I know the general number for technical support (123), but would like to call directly the local department that deals with mechanical damage to the line. Could you give me their direct number? 
English text:

I'm having problems with my home Internet service. Can I have the number to speak with someone about this?

Russian translation:

У меня дома не работает Интернет. Я знаю только общий номер техподдержки

- 123. Могли бы Вы дать мне прямой телефонный номер отдела обслуживания по месту жительства?

Russian-to-English translation:

The Internet in my home does not work. I know only the general number for technical support - 123. Could you give me the direct telephone number for the local service department?

3

English text:

I can't use my home Internet service. Who do I speak with about connectivity problems?

Russian translation:

у меня дома не работает Интернет. Не могли бы Вы дать мне телефонный номер отдела, который занимается проблемами со связью (не 123, а номер местного отделения)?

Russian-to-English translation:

The Internet in my home does not work. Could you give me the telephone number for the department that deals with connectivity issues (not 123, but the number for the local department)?

\section{Domestic phone service requests}


English text:

I'm having problems making domestic calls from home. I think that it might be an issue with the telephone jack or wiring. Could you give me the direct number of the department that deals with physical damage to the line?

Russian translation:

У меня дома не работает телефон. Я думаю, что проблемы с сервисом возникли из-за повреждения телефонной розетки или проводки. Я знаю общий номер техподдержки (123), но хотел бы позвонить напрямую в отдел, который занимается механическими повреждениями линии по моему месту жительства. Не могли бы Вы дать мне их прямой телефонный номер?

Russian-to-English translation:

The landline phone in my home does not work. I think that the problem with the service occurred due to mechanic damage to the telephone jack or wiring. I know the general number for technical support (123), but would like to call directly the local department that deals with mechanical damage to the line. Could you give me their direct number?

5

English text:

I'm having problems making domestic calls from home. Can I have the number to speak with someone about this?

Russian translation:

у меня дома не работает телефон. Я знаю только общий номер техподдержки

- 123. Могли бы Вы дать мне прямой телефонный номер отдела обслуживания по месту жительства?

Russian-to-English translation:

The landline phone in my home does not work. I know only the general number for technical support - 123. Could you give me the direct telephone number for the local service department? 
English text:

I can't make domestic calls from home. Who do I speak with about connectivity problems?

Russian translation:

у меня дома не работает телефон. Не могли бы Вы дать мне телефонный номер отдела, который занимается проблемами со связью (не 123, а номер местного отделения)?

Russian-to-English translation:

The landline phone in my home does not work. Could you give me the

telephone number for the department that deals with connectivity issues

(not 123, but the number for the local department)?

Our two types of requests (Internet/domestic phone service) are intended to capture different potentials of the two communication technologies to foster collective action. Compared to traditional phones, Internet communication should be more likely to be used to stage protest, and therefore perceived to be more threatening to the regime. Note that this does not presuppose that domestic phones cannot be used to organize collective action-of course they can, but the effectiveness of individual calls, and therefore the threat to the regime, is much lower. In other words, our two types of requests capture the latent treatment ("threat of collective action") only imperfectly, which will lead to measurement error in the treatment. However, since this error is random, it will lead to attenuation in our effect estimates, and should therefore be not be a real danger for our experiment. 


\section{Appendix S4: Other Email Elements}

\section{Name}

We sent each email from a name drawn randomly from the list below. These names are among the most popular Slavic names. ${ }^{6}$ Since Belarus is a patriarchy, respondents might be less likely to respond to messages from female senders. For this reason, we used all male names.
1. Борис Морозов
2. Артем Жук
3. Максим Кузнецов
4. Станислав Новик
5. Владимир Мельников
6. Дмитрий Волков

\section{Email addresses}

Each name is associated with a different email address, also listed below.
1. boris@bmorozov.org
2. artem@azhuk.org
3. maksim@mkuznetsov.org
4. stanislav@snovik.org
5. vladimir@vmelnikov.org
6. dmitry@dvolkov.org

\section{Subject Line}

We included in each email a subject line drawn randomly from the set of possible subject lines below. We do this to add some additional variation to the requests that service centers receive.

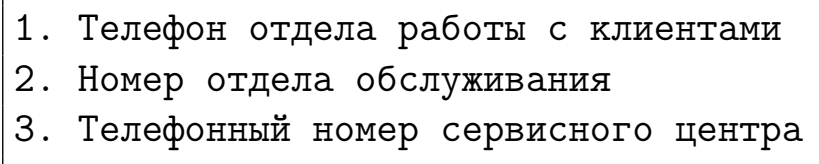

\section{Valediction}

We included in each email a valediction draw randomly from the set of possible valedictions below. We also randomized whether there is a line break between the request and the valediction. We did this to add some additional variation to the requests that service centers receive.

\footnotetext{
${ }^{6}$ Since there is no authoritative source on the popularity of names within Belarus, we selected these names based on conversations with Belarusian citizens.
} 
1. С уважением,

2. С наилучшими пожеланиями,

3. Искренне Ваш,

\section{Divider}

We included in each email a divider draw randomly from the set of possible dividers below. We placed the divider before the email signature. We did this to add some additional variation to the requests that service centers receive.

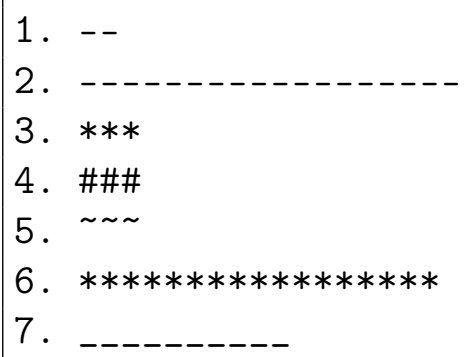




\section{Appendix S5: Complete LPM Results}

\begin{tabular}{|c|c|}
\hline \multicolumn{2}{|l|}{ Outcome: EmaIL Response } \\
\hline Pro-Regime & $\begin{array}{c}0.019 \\
(0.025)\end{array}$ \\
\hline Anti-REGIME & $\begin{array}{c}0.038 \\
(0.024)\end{array}$ \\
\hline INTERNET & $\begin{array}{c}0.019 \\
(0.026)\end{array}$ \\
\hline Pro-Regime $\times$ Internet & $\begin{array}{c}-0.019 \\
(0.034)\end{array}$ \\
\hline Anti-REgime $\times$ Internet & $\begin{array}{l}-0.047 \\
(0.033)\end{array}$ \\
\hline Constant & $\begin{array}{r}-0.017 \\
0.018\end{array}$ \\
\hline Support Center Fixed Effects & Yes \\
\hline
\end{tabular}

Table 1: Regression results, linear probability model. ${ }^{*} p<0.10 ;{ }^{* *} p<0.05$; ${ }^{* * *} p<$ 0.01 (two-tailed). Robust standard errors are show in parentheses. Data come from 636 observations that cover 106 centers over 6 time periods. The outcome measure is EMAIL RESPONSE. The reference group is emails with the non-partisan cue and the domestic phone service request. 


\section{Appendix S6: Conditional Logit Results}

\begin{tabular}{|c|c|}
\hline \multicolumn{2}{|l|}{ Outcome: EMAIL ResPonse } \\
\hline Pro-REGIMe & $\begin{array}{c}0.835 \\
(0.929)\end{array}$ \\
\hline AnTI-REGIME & $\begin{array}{c}1.864^{*} \\
(1.048)\end{array}$ \\
\hline INTERNET & $\begin{array}{c}0.835 \\
(0.929)\end{array}$ \\
\hline PRO-REGIME $\times$ INTERNET & $\begin{array}{l}-0.835 \\
(1.321)\end{array}$ \\
\hline Anti-REgime $\times$ InteRnet & $\begin{array}{l}-2.290 \\
(1.408)\end{array}$ \\
\hline Support Center Fixed Effects & Yes \\
\hline
\end{tabular}

Table 2: Conditional Logit results. ${ }^{*} p<0.10$; ${ }^{* *} p<0.05$; ${ }^{* * *} p<0.01$ (two-tailed). Standard errors are show in parentheses. Data come from 636 observations that cover 106 centers over 6 time periods. The outcome measure is Email REsPonse. The reference group is emails with the non-partisan cue and the domestic phone service request. 


\section{Appendix S7: Alternative Dependent Variable}

Do our results hold for our Helpful Email measure? Before answering this question, we first examine the data. Figure 4 provides an overview of our HELPful EMAIL. As a reminder Helpful Email, is coded 1 if we received a helpful response and 0 otherwise. The left panel provides frequency counts for the outcome's two values. The right panel shows the number of centers that did not send a helpful reply to any of our emails (including centers that did not send any reply) and the number of centers that sent a helpful reply to at least one of our emails. Only 6.3 of our requests received a helpful reply.
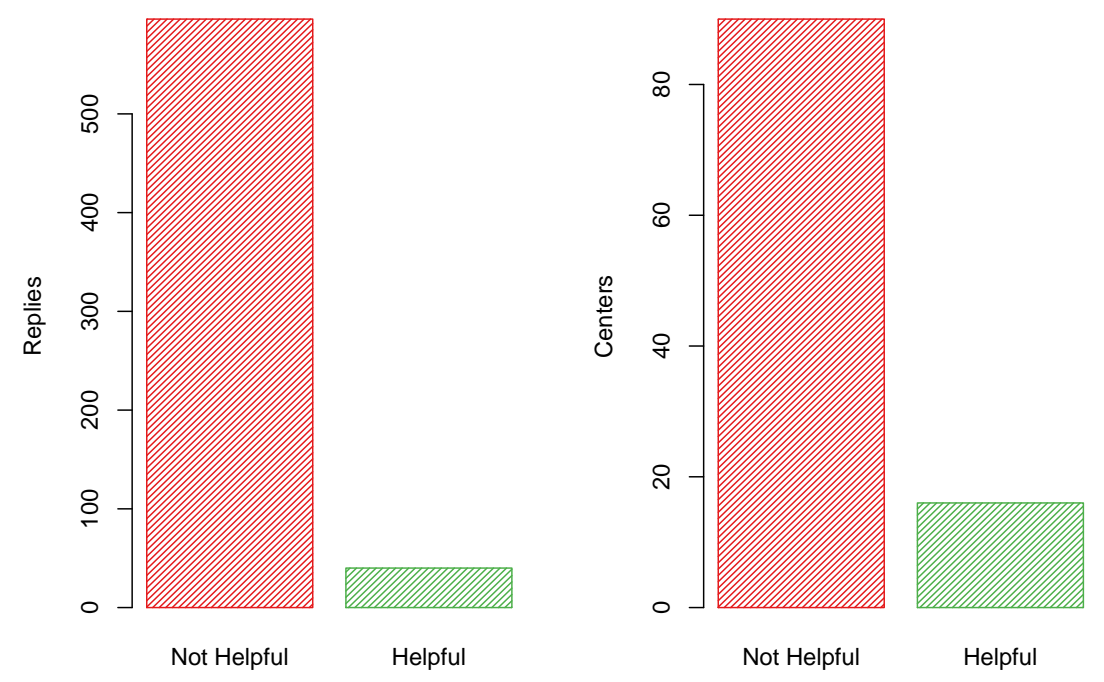

Figure 4: Overview of our Helpful Email variable. The left panel provides frequency counts for the outcome's two values. The right panel shows the number of centers that did not send a helpful reply to any of our emails (including centers that did not send any reply) and the number of centers that sent a helpful reply to at least one of our emails.

To test if our treatments influenced support center helpfulness, we estimate another LPM model with Helpful Email as the outcome measure (see Table 3. Figure 5 presents the results from this model graphically. The left panel plots the estimated coefficients (black points) from the model along with $90 \%$ confidence intervals (gray bars). The reference group is emails with the non-partisan cue and the domestic phone service request. As in Figure 3 in the main text, the plot shows that the estimated coefficient for ANTI-REGIME $\times$ INTERNET is negative. This might suggest that regime opponents are less likely to receive a response when they send an Internet request as opposed to a telephone request. The uncertainty around this estimate, however, prevents us from making strong claims based on these results. 
The right panel plots the marginal effect of ANTI-REGIME across request types (black points) along with $90 \%$ confidence intervals (gray bars). We should see that the effect of the anti-regime treatment is negative when it appears in emails that contain Internet-related requests. This is what we find, though the $90 \%$ confidence interval for this marginal effect contain 0 .

Outcome: Helpful Email

\begin{tabular}{|c|c|}
\hline PRO-REGIME & $\begin{array}{c}0.000 \\
(0.019)\end{array}$ \\
\hline ANTI-REGIME & $\begin{array}{c}0.019 \\
(0.022)\end{array}$ \\
\hline INTERNET & $\begin{array}{l}-0.009 \\
(0.018)\end{array}$ \\
\hline PRO-REGIME $\times$ INTERNET & $\begin{array}{c}0.009 \\
(0.027)\end{array}$ \\
\hline ANTI-REGIME $\times$ INTERNET & $\begin{array}{l}-0.038 \\
(0.029)\end{array}$ \\
\hline Constant & $\begin{array}{l}0.003 \\
0.014\end{array}$ \\
\hline Support Center Fixed Effects & Yes \\
\hline
\end{tabular}

Table 3: Regression results, linear probability model. ${ }^{*} p<0.10$; ${ }^{* *} p<0.05$; ${ }^{* * *} p<$ 0.01 (two-tailed). Robust standard errors are show in parentheses. Data come from 636 observations that cover 106 centers over 6 time periods. The outcome measure is HELPFUL EMAIL. The reference group is emails with the non-partisan cue and the domestic phone service request. 

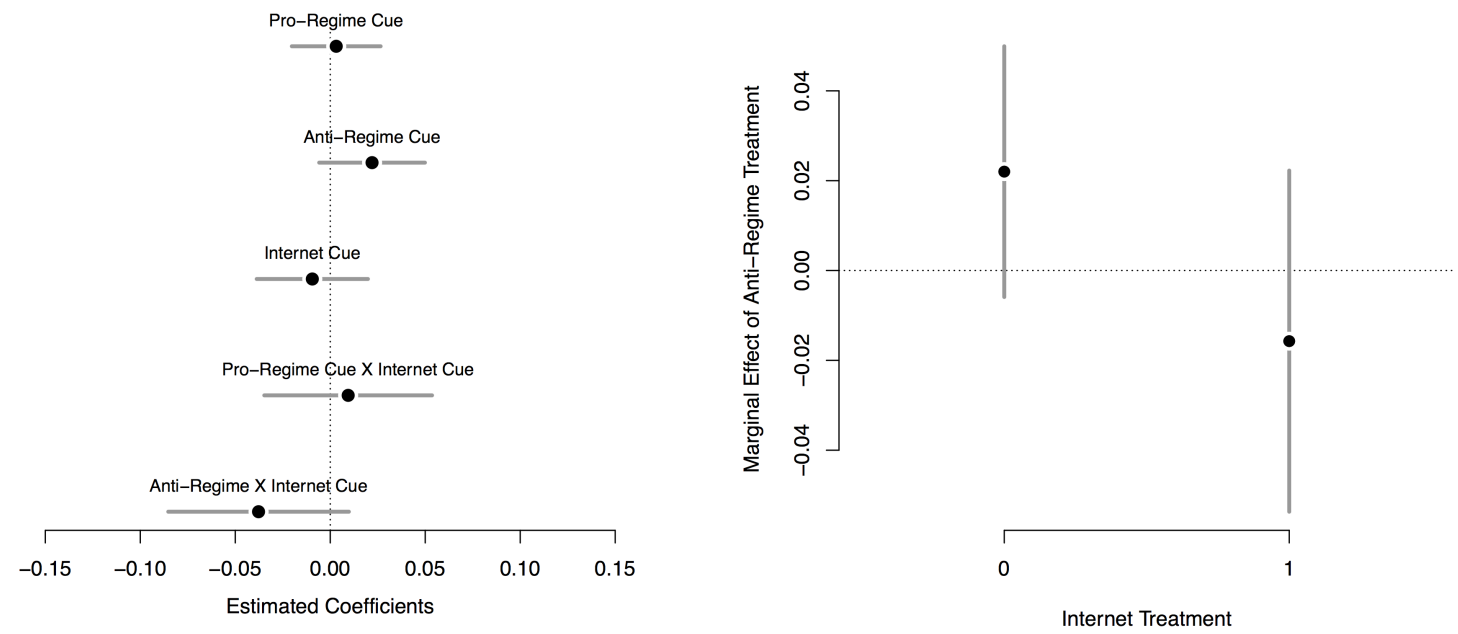

Figure 5: Results of LPM model. The outcome measure is EMAIL RESPONSE. The left panel plots the estimated coefficients (black points) from the model along with $90 \%$ confidence intervals (gray bars). The reference group is emails with the non-partisan cue and the domestic phone service request. The right panel plots the marginal effect of ANTI-REGIME across request types (black points) along with 90\% confidence intervals (gray bars). 